\title{
Emotional Maturity of Working and Non-Working Women
}

\author{
Kiranben Vaghela*
}

\section{ABSTRACT}

Present research has done to know the effect of Working and Non Working Women on Emotional Maturity. For this Total number of sample was 60 in which 30 working women from the age group of 20 to 40 years. And 30 non working women were taken the same age group. For the data collection Emotional maturity scale developed by Roma Pal (1988) was used for data analysis and concluded result ' $t$ ' test was used. For this dimension implies that in positive sense there was significant difference between working and non working women. The result indicate the working women significantly differ on Emotional maturity score as compared to non working women, working women have shown better Emotional Maturity compared to non working women .

Keywords: Emotional Maturity

\section{INTRODUCTION}

Emotion is the complex psycho physiological experience of an individual's state of mind as interaction with biochemical (internal) and environmental (external) influences. In humans, emotion fundamentally involves "physiological arousal, expressive behaviours and conscious experience." Emotion is associated with mood, temperament, personality, disposition, and motivation. Motivations direct and energize behaviour, while emotions provide the affective component to motivation, positive or negative. A related distinction is between the emotion and the results of the emotion, principally behaviours and emotional expressions. People often behave in certain ways as a direct result of their emotional state, such as crying, fighting or fleeing. If one can have the emotion without a corresponding behaviour, then we may consider the behaviour not to be essential to the emotion.

*PhD Scholar, Department of Psychology, Sardar Patel University, Vallabh Vidhya Nagar Anand 


\section{Emotional Maturity of Working and Non-Working Women}

The emotional aspect of maturity is the most important factor in the development of the comprehensive mature personality, especially for the gifted. This is the global factor of emotional maturity which is the strength to actualize individual abilities within the frame of social demands.

According to Goleman (1995), we have two minds, one that thinks and one that feels, these two fundamentally different ways of knowing, interact to construct our mental life. The rational mind is the mode of comprehension we are typically conscious of more prominent in awareness, thoughtful, able to ponder and reflect. The emotional mind is impulsive and powerful and sometimes illogical. These two minds operate in harmony with each other, most of times feelings are essential to thought, and most of the times thoughts to feeling. But when passions surge the balance tips: it is not just I.Q., but emotional intelligence that matters. Goleman rightly points out that, "It is not that we want to do away with emotions and put reason in its place, but instead find an intelligent balance of two".

According to Walter D. Smitson (1974) emotional maturity is a process in which the personality is continuously striving for greater sense of emotional health, both intra physically and intra-personally.

Kaplan and Baron elaborate the characteristics of an emotionally mature person, say that he has the capacity to withstand delay in satisfaction of needs. He has the ability to tolerate a reasonable amount of frustration. He has belief in long-term planning and is capable of delaying or revising his expectations in terms of demands of situations. An emotionally mature child has the capacity to make effective adjustment with himself, members of his family and his peers in the school, society and culture. But maturity means not merely the capacity for such attitude and functioning but also the ability to enjoy them fully.

There are many various factors are put its effect on Emotional Maturity one of them is women. Present research is done to know that effect of working and non working women on Emotional Maturity.

\section{PROBLEM OF STUDY}

The problem of the present study is as under:

"A Comparative study of Emotional Maturity among working and non working women"

\section{OBJECTIVES OF THE STUDY}

The main objectives of present study are as under:

1. To study of the Emotional Maturity among working and non working women.

2. To study and compare the various dimension of Emotional Maturity of working and non working women.

\section{HYPOTHESIS}

The main hypotheses of present study are as under:

1. There is no significant difference between working and non working women in various dimension of Emotional Maturity.

2. There is no significant difference between working and non working women in Emotional Stability. 


\section{Emotional Maturity of Working and Non-Working Women}

3. There is no significant difference between working and non working women in Emotional Regression.

4. There is no significant difference between working and non working women in Faulty Social adjustment.

5. There is no significant difference between working and non working women in Lack of Independency.

6. There is no significant difference between working and non working women in Flexibility.

\section{VARIABLES}

The variables of present study are having given in following.

\section{*In dependent variable:}

Working and non working women.

**Dependent variable :

Various dimension of Emotional Maturity are measured by Roma Pal (1988)

\section{SAMPLE:}

The main aim of the present research is "A comparative study of Emotional Maturity of working and non working women". For this total no of sample were 60 in which 30 working women from the age group of 20 to 40 years. And 30 non working women were taken from the same age group.

\section{TOOL:}

Emotional maturity scale developed by Roma Pal (1988) was used to measure emotional maturity the scale contains 40 items with totally agree, neutral, generally, disagree and totally disagree. Response alternative the responses were marked 5,4,3,2 and 1 respectively and from the responses we had to select only one response in every sentence. 5 for tick mark totally agree, 4 for tick mark agree, 3 for tick mark neutral, 2 for tick mark disagree and 1 for tick mark totally disagree. The maximum possible score is 200 and minimum is 40 .Scoring pattern shows that more score indicates less emotional maturity. The less score in the scale indicates good (more) emotional maturity.

The reliability score of emotional maturity scale comes to 0.84 , derived by the split half method, obtained from the sample of 200 students. The researcher of the present research has found out the reliability score as 0.81 , by using split-half technique on the sample of 50 students.

\section{PROCEDURE}

After establishing report Emotional Maturity inventory were administered individuals to every subject. All the instruction were strictly following which are been given the manual of inventory. The responses of inventory have scored as per scoring keys. This has given in the manual of inventory. The data was categories and arranged in respective table according to the stoical technique appraised. 


\section{STATICALLY ANALYSIS}

The main aim of the present research is to study and compare to Emotional maturity between working and non working women. Scoring was done as per scoring key of the inventory to examine significantly difference between working and non working women. For data analysis ' $t$ ' test was used.

\section{RESULTS}

Table: $1 \quad \mathbf{N}=\mathbf{6 0}$ Show in Mean, $\mathrm{SD}$, and ' $\mathrm{t}$ ' ratio of various group of age on score of various dimensions of mental health

\begin{tabular}{|c|c|c|c|c|c|c|}
\hline $\begin{array}{l}\text { Dimension of Emotional } \\
\text { Maturity }\end{array}$ & Group & $\mathbf{N}$ & Mean & SD & ' $t$ ' & $\begin{array}{l}\text { Significant } \\
\text { level }\end{array}$ \\
\hline \multirow{2}{*}{ Emotional instability } & $\begin{array}{l}\text { Working } \\
\text { women }\end{array}$ & 30 & 33.87 & 3.3 & 3.87 & \multirow[t]{2}{*}{0.01} \\
\hline & $\begin{array}{l}\text { Non } \\
\text { working } \\
\text { women }\end{array}$ & 30 & 30.23 & 3.96 & & \\
\hline \multirow[b]{2}{*}{ Emotional Regression } & $\begin{array}{l}\text { Working } \\
\text { women }\end{array}$ & 30 & 28.1 & 3.65 & 1.46 & \multirow[b]{2}{*}{$\mathrm{NS}$} \\
\hline & $\begin{array}{l}\text { Non } \\
\text { working } \\
\text { women }\end{array}$ & 30 & 26.67 & 4 & & \\
\hline \multirow[b]{2}{*}{ Faulty social adjustment } & $\begin{array}{l}\text { Working } \\
\text { women }\end{array}$ & 30 & 37.57 & 4.89 & 2.4 & \multirow[b]{2}{*}{0.05} \\
\hline & $\begin{array}{l}\text { Non } \\
\text { working } \\
\text { women } \\
\end{array}$ & 30 & 34.23 & 5.88 & & \\
\hline \multirow[b]{2}{*}{ Lack of Independency } & $\begin{array}{l}\text { Working } \\
\text { women }\end{array}$ & 30 & 19.1 & 2.69 & 3.01 & \multirow[b]{2}{*}{0.01} \\
\hline & $\begin{array}{l}\text { Non } \\
\text { working } \\
\text { women }\end{array}$ & 30 & 16.69 & 3.45 & & \\
\hline \multirow[b]{2}{*}{ Flexibility } & $\begin{array}{l}\text { Working } \\
\text { women }\end{array}$ & 30 & 28.1 & 3.12 & 3.64 & \multirow[b]{2}{*}{0.01} \\
\hline & $\begin{array}{l}\text { Non } \\
\text { working } \\
\text { women }\end{array}$ & 30 & 25.33 & 2.79 & & \\
\hline \multirow[b]{2}{*}{ Overall emotional maturity } & $\begin{array}{l}\text { Working } \\
\text { women }\end{array}$ & 30 & 18.7 & 12.2 & 2.29 & \multirow[b]{2}{*}{0.05} \\
\hline & $\begin{array}{l}\text { Non } \\
\text { working } \\
\text { women }\end{array}$ & 30 & 17.29 & 10.1 & & \\
\hline
\end{tabular}




\section{DISCUSSION}

Emotional Maturity of Working and Non-Working Women

In result table an attempt is to find out the different between working and non working women in various dimension of Emotional Maturity score with ' $t$ ' test.

' $t$ ' value of working and non working women of Emotional instability score is 3.87, which is significant act 0.01 level. It means working women are significant differ on Emotional instability Positive score as compare to non working women. Working women have shown better Emotional instability by getting high mean score $\mathrm{M}=33.87$ then non working women mean $\mathrm{M}=30.23$.

' $t$ ' value of working and non working women of Emotional regression is 1.46 which is not significant. Working women have shown better Emotional regression by getting high mean score $\mathrm{M}=28.10$ then non working women $\mathrm{M}=26.67$

' $t$ ' value of working and non working women of Faulty social adjustment is 2.40 which is significant at 0.05 level. It means working women are significant differ on Faulty social adjustment score as compare to non working women. Working women have shown better Faulty social adjustment by getting high mean score $M=37.57$ then non working women $\mathrm{M}=34.23$

' $t$ ' value of working and non working women of Lack of Independency is 3.01 which is significant at 0.01 level. It means working women are significant differ on Lack of Independency score as compare to non working women. Working women have shown better Lack of Independency by getting high mean score $M=19.10$ then non working women $\mathrm{M}=16.69$

' $t$ ' value of working and non working women of Flexibility is 3.64 which is significant at 0.01 level. It means working women are significantly differ on Flexibility score as compare to non working women have shown better Flexibility score as compare to non working women. Working women have shown better Flexibility by getting high mean score $\mathrm{M}=3.12$ then non working women $\mathrm{M}=2.79$.

' $t$ ' value of working and non working women of overall Emotional maturity is 2.29 which is significant at 0.05 level. It means working women are significant differ on overall Emotional maturity score as compare to non working women. Working women have shown better overall Emotional maturity by getting high mean score $M=18.70$ then non working women $\mathrm{M}=17.29$.

\section{REFERENCES}

1. Arun joseph(2010). Meaning and definition of emotional maturity. Data retrieved on 11 agu 2011 from http//:arunarun joseph. Blogspot.com 2010 /03/study-of-emotional maturity-and-html.

2. Arya, A. (1997). Emotional Maturity and values of superior children in family. Fourth survey of research in Education Vol.11, New Delhi: NCERT.

3. Coleman,(1994).Definition of emotional maturity. data retrieved on 12 oct 2009,from ssmrae.com/admin/.../37802308c3531dffab3bddd71e963e04.pdf 


\section{Emotional Maturity of Working and Non-Working Women}

4. Landau, E. (1998). The Self- The Global factor of Emotional Maturity. Journal Article, Roeper Review, Vol.20. 1998.

5. Singh, $\mathrm{Y}$ and Bhargava, M, Manual for Emotional Maturity Scale (Ems), National Psychological Corporation, Agra, 1990.

6. Walter,D. and simston W.S (1974).Definition of emotional maturity.MH.winter.58:9-11. 